\title{
SEASONAL ABUNDANCE OF THE PLUM SCALE INSECT PARLATORIA OLEAE (COLVEE) (HOMOPTERA: DIASPIDIDAE) ON THE OLIVE TREES IN NEWLEY RECLAIMED AREAS
}

\author{
HASSAN, A. SH. ${ }^{1}$, M. M. MANSOUR ${ }^{2}$ AND M. A. EL-DEEB ${ }^{2}$ \\ 1. Plant Protection Research Inst. , ARC, Dokki, Giza \\ 2. Plant Protection Dept., Fac. Agric., Zagazig University \\ (Manuscript received 22 March 2009)
}

\begin{abstract}
Field studies were conducted under different conditions of Sharkia Governorate (El-Khattara region) to study the ecological aspects of Parlatoria oleae (Colvee) (Homoptera: Diaspididae) on olive trees during two successive seasons 1994 and 1995. The obtained data showed that three peaks of activity of Parlatoria oleae, in January, April and August in outer zone and in January, March, August in inner zone in the first year 1994 and in February, August, October in outer zone, and in January, March, August in inner zone in the second year 1995. The highest peak was recorded in January for all zones during the two years except outer zone, which recorded in February1995. For both years three overlapping generations were recorded in inner zone, while in outer zone two overlapping generation were showed. The powerful generation was the last generation for both zones during two years. The total percentage of parasitism in inner zone was higher than outer one in both years. Aphytis sp., Merietta connecta and Merietta picta were the main parasitoids on $P$. oleae. Temperature and sunny shine has almost positive significant effect on all tested stages, while R.H \% with sunny shine had a significantly negative effect.
\end{abstract}

\section{INTRODUCTION}

Olive trees (Olea europea) is considered as one of the most important fruit crops in newly reclaimed areas. According to the journal of Agriculture Economic (Ministry of Agriculture) 1986 and 1996, the total cultivated area of olive trees in Egypt has been rapidly increase and reached to about 6248 feddans producing a yield of approximately 8787 tons olive fruits. Trees areas increased during few year and reached about 82685 fiddans in (1996) producing a yield of approximately 208133 tons for the same crop.

Scale insects and mealy bugs are usually considered as the most important pests on fruit trees.

Applebaum and Rosen (1964) \& Shalom and Rosen (1964) stated that the olive scale, Parlatoria. oleae had two generations annually on diciduous fruit trees and on olive trees. Hafez (1967) recorded that the highest population was showed in AprilMay in the lower zones of the trees followed by the middle zones and the lowest 
population at the upper zones of the trees. The insect distribution at different directions was insignificantly affected. The population tended to occur at the lower zone of the tree and the lowest population at the upper zone. Temperature, wind, light intensity and foliage density combined together are the main factors controlling the mode of distribution of the plum scale on pear trees in different seasons. Gomaa, (1978) in Bulgaria \& Argyrious and Kourmadas, (1979), in Greece reported that there were two generations for $P$ oleae a. year.

Kamal-EL-Din, (1983) Showed that $P$. oleae had 3 annual generations on olive leaf from the first of February until the end of June, the second, from the end of June until the end of September, while the third generation appeared from the beginning of October until the end of February. El-Hakim and Helmy, (1985) mentioned that $P$. oleae was found on the leaves of olive trees in Egypt and had three peaks in Tora and Fayoum district, while it had two peaks in Alexandria district. ElBolok et al., $(1985, a, b)$ recorded that Parlatoria zizyphus, had two annual generations, the first occurred in April- May, and the second occurred in September- October in both, (1982 - 1983). And also they recorded the effect of height and directions of the trees and leaf surface on the distribution of the insect population for $P$. zizyphus on sour orange leaves throughout 1982 and 1983, the highest population density of nymphs and adults tended to be harboured in the lower level of the trees (21.9 and 20.8 nymphs $\left./ 4 \mathrm{~cm}^{2}\right)$ and $\left(34.7,33.4\right.$ adults $\left./ 4 \mathrm{~cm}^{2}\right)$ in 1982-1983 respectively. While the lowest one occurred in upper level of the trees during the period of the investigation (18.9 and 20.4 nymphs $4 \mathrm{~cm}^{2}$ ) and $\left(29.8,30.7\right.$ adults $\left.4 \mathrm{~cm}^{2}\right)$ in 1982 1983 respectively. Directions of the trees and tree core had a slight effect. The highest population density of adults in both seasons occurred at western and southern directions of the trees, while lowest population density occurred at core Eastern and Northern. The majority of scales were found on the upper surface of the leaf. The distribution of the insect could be arranged as follows: autumn, spring, summer and winter, respectively. Moursi and Hegazi, (1985) found that the scale insect $P$. oleae had three overlapping generations a year on olive trees. Moursi and Mesbah, (1985) found that $P$. oleae had two peaks in (Burg EL-Arab) occurring in March and AugustSeptember.

Rizk and Mohamad, (1985) in Iraq, showed that $P$. oleae, had two annual generations, the first started towards the end of April, while the second or the full generation started at mid August and extended to the second half of April. Cermeli, (1993) in Spain, obtained results indicating the occurrence of two generations of $P$. oleae on plum trees. Nahla-Abdel-Halleem. (1997) recorded that $P$. oleae had three 
annual generations on deciduous trees (plum, peach and apricot) during two successive years, (1993 and 1994) in Wadi EL-Natrun, and EL-Kanater EL-Khairiya.

This present paper was carried out at El-Khattara region El-Sharkia Governorate to determined the population density and number of generations of $P$. oleae (Colvee) and its associated parasitoids on olive trees pest. It cause an economic damage to the plant which become on important fruit crop for the most farmers at newly reclaimed areas.

\section{MATERIALS AND METHODS}

The present work was carried out at El-Khattara region, El-Sharkia Governorate, during two successive years (1994 and 1995).

Eight olive trees of similar in age, size and vegetation at El-Kattara experimental farm, Agric., Fac., of Zagazig Univ. 120 leaves were picked up at random in each outer and inner zone/tree. The total numbers of leaves in every sample were 960 ( 8 tree $\times 120$ leaves). Biweekly samples were taken from January 1994 untill December 1995. These samples were chosen randomly from different heights and directions and kept in polyethylene bags, then samples were transferred to the laboratory and examined by the aid of sterio-microscope binocular. Alive and dead stages and parasitoids on both surfaces of the leaves were recorded. Weather factors were obtained from the nearest meterorological station, also light intensity measured by luxmeter in both outer and inner zones, when the sun was perpendicular on the earth 12 a.m.

Statistical analysis was studied using simple correlation and partial regression, Fisher, (1950).

\section{RESULTS AND DISCUSSION}

\section{Seasonal abundance of the plums cale insect Parlatoria oleae (Colvee) :}

This species is one of the most important scale insect infesting fruit trees especially olive plume and pear trees in Egypt.

Seasonal abundance of different stages and their peaks of activity for each stage were recorded. The activity periods of associated parasitoids on (olive trees) and prevailing climatic factors (temperature, relative humidity, sunny shine and light intensity) were also studied. The obtained results which presented in Tables, $(1,2,3$ \& 4) and Figs (1, 2, 3 and 4) revealed the following findings: 


\section{Female populations}

Three peaks were calculated in outer zone during, the first season 1994, the first and highest peak was in February (838 females), while the second one was recorded in August (198 females), and the latter in November (113 females) (Table 1). In inner zone also three peaks were also noticed in January (4488 females), March (1320 females) and July (516 females), where the highest one was in January (Table 2).

In the second season 1995, two peaks were recorded in outer zone in February (216) and July (335) while in inner zone three peaks were recorded in January (1124), March (332) and July (124) in which the highest peak was in January (Table 3, 4).

During the first season, the total number of females in tree inner zone was higher than in the outer zone and this phenomenon completely reversed during the second consecutive season, (1995).

\section{Male population:}

In the first season 1994 four peaks were recorded in outer zone during January (2134 males), April (1188 males), September (1056 males) and November (1144), while in inner zone three peaks were recorded in April, (1320 males), July (1848 males) and December (2376 males). The highest number of males population in outer zone was found in January (2134 males), while the highest one in inner zone was in December (2376 males) (Table 1, 2).

In the second season 1995 two peaks were recorded in outer zone in February (1045 males) and October (858 males), the highest peak was in February (1045 males), while in inner zone three peaks were recorded in April, (328 males) July (460 males) and December (592 males) with the highest and last peak of (592 males) (Table 3, 4).

The total numbers of males were higher in the first season than that the second one, (Tables1, 2, 3 and 4).

\section{Nymphs population:}

Data obtained showed that during first season 1994 numbers of nymphs stage were higher in inner zone than in outer one (Table 1, 2). Two peaks were recorded in outer zone throughout January, (484 nymphs) and August, (1161 nymphs), while in inner zone three peaks were recorded in January, (528 nymphs), June (672 nymphs) and August, (1056 nymphs) the highest one was in August (1056 nymphs). The highest peak occurred in August for both inner and outer tree zones .

In the second season 1995 three peaks were recorded for both zones where they were recorded in May (289 nymphs), Aug (442 nymphs) and October (308 
nymphs) in outer zone. In inner zone, they were in January (132 nymphs), June (168 nymphs), and August (264 nymphs). The highest peaks for both zones were recorded in August.

Generally, it could be noticed that numbers of nymphs in the first season 1994 were higher than in second one also the total number of nymphs in inner zone was higher than in outer zone during the first season 1994, while the reverse was noticed in the second season 1995.

\section{Total number of alive scale insects:}

Population density of $P$. oleae on olive trees was estimated by counting the total numbers of all alive stages during two successive seasons 1994 and 1995. During the first season three peaks of activity for both zones occurred in January (3388 individuals), April (1502 individuals) and August (1909 individuals) in outer zone, with a highest peak in January (3388 individuals) while in the inner zone, the peaks of activity were recorded in January (6600 individuals), March (2376 individuals) and August (2904 individuals) with a highest one in January (Tables 1, 2).

In the second season 1995, also three peaks of activity were recorded for both zones in February (1373 individuals), August (1088 individuals) and October (1232 individuals) in outer zone, the highest one was observed in February (Table 3). In inner zone three peaks were also recorded in January (1652 individuals), March (592 individuals) and August (708 individuals), and the highest one was in January (Table 4).

The total numbers of alive stages of $P$. oleae on olive trees in the first season, 1994 was higher than that of the second one, this my be due to climatic factors and the activity of parasite during the two seasons.

\section{Total of non-alive and percentage of mortality insects:}

Data obtained in Tables, $(1,2,3$ and 4), show that the total numbers and percentage of mortality insects in the first season, 1994 was higher than in the second one 1995 especially in inner zone during both seasons. The mortality rates averaged were reached to $(61.3 \%)$ in outer and $(71.9 \%)$ in inner zone during, 1994 , while they were $(49.2 \%)$ in outer and $(71.9 \%$ o) in inner zones during, 1995.

\section{Percentage of parasitism:}

Data given in Tables, (1\&2), indicated that there were four peaks were recorded during the first season 1994 in both zones. In outer zone, peaks were recorded in March $(10.1 \%)$, June (13.6\%), September (11.3\%) and December $(20.4 \%)$, with the highest one in December, $(20.4 \%)$. While in inner zone the peaks were recorded in January (15.5\%), April (18.1\%), August $(29.6 \%)$ and October $(31.3 \%)$ with the highest one in October.

In the second season 1995, three peaks were recorded in outer zone during February (14.5\%), July (16.5\%) and December (15.8\%), where the highest one was in July (16.5\%). In inner zone, four peaks were recorded in January (15.5\%), April (18.1 
$\%)$, August (29.7\%) and October (30.0\%) the highest peak was recorded in October (Table 4). The total percentage of parasitism in inner zone was higher than outer one, in both seasons.

According to the above mentioned results, many authors showed that Aphytis maculicornis was the main dominate parasite on P. oleae, Hafez and Doutt (1954), Huffaker et al., (1962), Kennett et al. (1966), Moursi and Mesbah (1985), Fawzia. Hassanein \& Hamed (1985), and Cohen (1993) Moreover, Huffaker et al (1962) mentioned that the level of scale activity could be co-elated with the parasite activity in spring season.

Also Moursi and Mesbah, (1985) stated that the parasitism by $A$. maculicomis on olive pests reached the maximum during July 1982 (20\%), January and May (22\% and $30 \%$, respectively).

\section{Effect of climatic Factors:}

7.1. On Female: Data obtained in Tables $(5,6,7$ and 8) show that in the first season, 1994 a negative significantly effect was observed for both outer light intensity and sunny shine in outer and inner zones where $r=-0.6081 *$ and $-0.6846 *$, respectively.

In the second season, 1995 only inner light intensity had a negative significantly effect where ( $r=-0.6259 *)$.

7.2. On Male: In Tables (5\&7) it could be noticed that during the first season 1994 in outer zone, sunny shine had a highly significantly negative effect where ( $r=$ $\left.0.7213^{* *}\right)$, while in the second season, 1995 relative humidity had a positively significant effect in outer zone, $(r=0.6176 *)$ (Table 7$)$.

7.3. On total number of alive scaleinsects: Data given in Tables $(5,6,7$ and 8$)$ show a significant negative effect for sunny shine in both zones in the first season 1994, $\left(r=-0.6962^{*}\right.$ and $\left.-0.6268^{*}\right)$, respectively, while in the second season 1995 a positively significant and negatively significant effects were recorded for both $\mathrm{R} . \mathrm{H} \%$ in inner and inner light intensity where values $\left(r=-0.6669^{*}-0.6386 *\right)$, respectively.

7.4. On total of non-alive scale insects: The effect of climatic factors on dead numbers cleared that in the first season, 1994 a negatively significant effect of outer light intensity in outer zone, was recorded $\left(r=-0.6364^{*}\right)$, while in inner zone a negatively significant effect of temperature $\left(r=-0.5988^{*}\right)$. Also, Sunny shine has a highly negative effect, $(r=-0.7100 * *)$.

In the second season, 1995 in inner zone only a negative highly significantly effect of inner light intensity was recorded, $\left(r=-0.7106^{* *}\right)$ Table (8).

7.5. Percentage of total mortality: During the first season, 1994 there was no influence of climatic factors recorded Tables (5 \&6).

In the second season 1995, R.H\% in outer zone had a highly negative significantly effect was recorded $(r=-0.7260 * *)$, while in inner zone a negatively significant effect occurred for temperature $(r=-0.6050 *)$, Tables $(7 \& 8)$. 
7.6. On percentage of parasitism: Data given in tables $(5,6,7$ and 8$)$ Cleared that there was no actually significantly effects during the two investigated seasons, 1994 and 1995.

\section{Combined effect of climatic factors:}

Statistical analysis of the combined effects between climatic factors and different stages Tables (5, 6, 7 and 8 ) indicated the following:

\subsection{In the first season 1994:}

a) in outer zone, there was and a positively highly significant effect between both of temperature sunny shine and outer light intensity, $\left(r=-0.8123^{* *}\right)$ and $\left(0.9151^{* *}\right)$, respectively. A positively highly significantly effect was found between sunny shine and outer light intensity, $(r=0.8244 * *)$.

b) The combined effect between R.H\% and both of outer light intensity and sunny shine had a negatively significant effect, $\left(r=-0.5785^{*}\right.$ and $\left.-0.5866^{*}\right)$, respectively.

c) In inner zone in the same season, 1994 there was a positive highly significantly effect between temperature and sunny shine, ( $r=$ $\left.0.8123^{* *}\right)$. On the other hand, in the same zone there was a negatively significantly effect between R.H\% and sunny shine $\left(r=-0.5866^{*}\right)$ Table, (6).

\subsection{In the second season 1995:}

d) In outer zone there was a positive highly significantly effect between temperature and sunny shine, $\left(r=0.9115^{* *}\right)$, also, between sunny shine and outer light intensity, $\left(r=0.6323^{*}\right)$.

On the other hand, in the outer zone a negative highly significantly effect was found between R.H\% and sunny shine, ( $r=-0.6 .299 *)$ while in inner zone, a positive highly significant effect was recorded between temperature and sunny shine $\left(r=0.9115^{* *}\right)$, while, a negative significantly effects, were found between R.H\% and sunshine, $\left(r=-0.6299^{*}\right)$.

Generally, it could be noticed that temperature and sunny shine had almost a positive highly significant effect in all cases, while R.H\% with sunny shine had a negative significantly effect.

\section{Number of generations.}

As $P$. oleae is known to have overlapping generations, it was necessary to utilize the formula proposed by Audemard and Milaire (1975) and emended by Jacob (1977) for estimating the number and duration of its annual generations. Data of monthly counts of nymph stage shown in (Table 9, 10) and illustrated in (Figs. 5, 6) show that.

In the first season 1994 (Table, 9) and Fig (5) inner zone showed that $P$. oleae had three generations, the first took about five months from the beginning of 
January till the end of May. The maximum number of nymphs, occurred during January (528 nymphs) the second generation occupied nearly two months from the beginning of June till the end of July and the third generation was about five months from the beginning of August till the end of December. The maximum nymph numbers occurred during August (1056 nymphs).

In outer zone, two overlapping generations were recorded, the first one took about 7 months from the beginning of January till the end of July where the maximum number of nymphs occurred in January (484), the second generation took about five months from the beginning of August till the end of December, with a maximum population (1161) in August.

In the second season 1995, (Table 10) and (Fig. 6) P. oleae had three overlapping generations in inner zone, the first generation took about 5 months from the beginning of January till the end of May. The maximum counts of nymphs occurred in January (132), while the second generation was the weakness one lasted two months from the beginning of June till the end of July. The third generation was the highest one, where numbers of nymphs were (264) in August and took about 5 months from the beginning of August till the end of December (Fig 6).

Two overlapping generations were recorded in outer zone 1995, the first took about 7 months from the beginning of January till the end of July and the second generation took about 5 months from the beginning of August till the end of December where the highest number of nymphs occurred in October (308 nymphs).

Generally, data giving in Figs ( 5 and 6 ) showed that the last generation of Parlatoria oleae for both zones during the two years of study represented the longest and highest number of nymphs. Three generations were recorded, in inner zones while in outer zone two generations were recoded.

From the aforementioned results it could be noticed that number of generations was differed between 2-3 generations. Same results were obtained by Applebaum and Rosen, (1964), Shalom and Rosen, (1964) on deciduous fruit orchard, kuznetsov, (1966) on all species of pine Gommaa, (1978), Kamal (1983), El-Hakim and Helmy, (1985), Moursi and Hegazi, (1985) on leaves olive, Moursi and Mesbah, (1985) on olive trees, Rizk and Mohamed, (1985) and Cermeli, (1993) on plume trees. Abou- Setta (1981), and Mahmoud, (1981), who stated that number of generation of $P$. oleae was differed from season to another and from region to another region. 

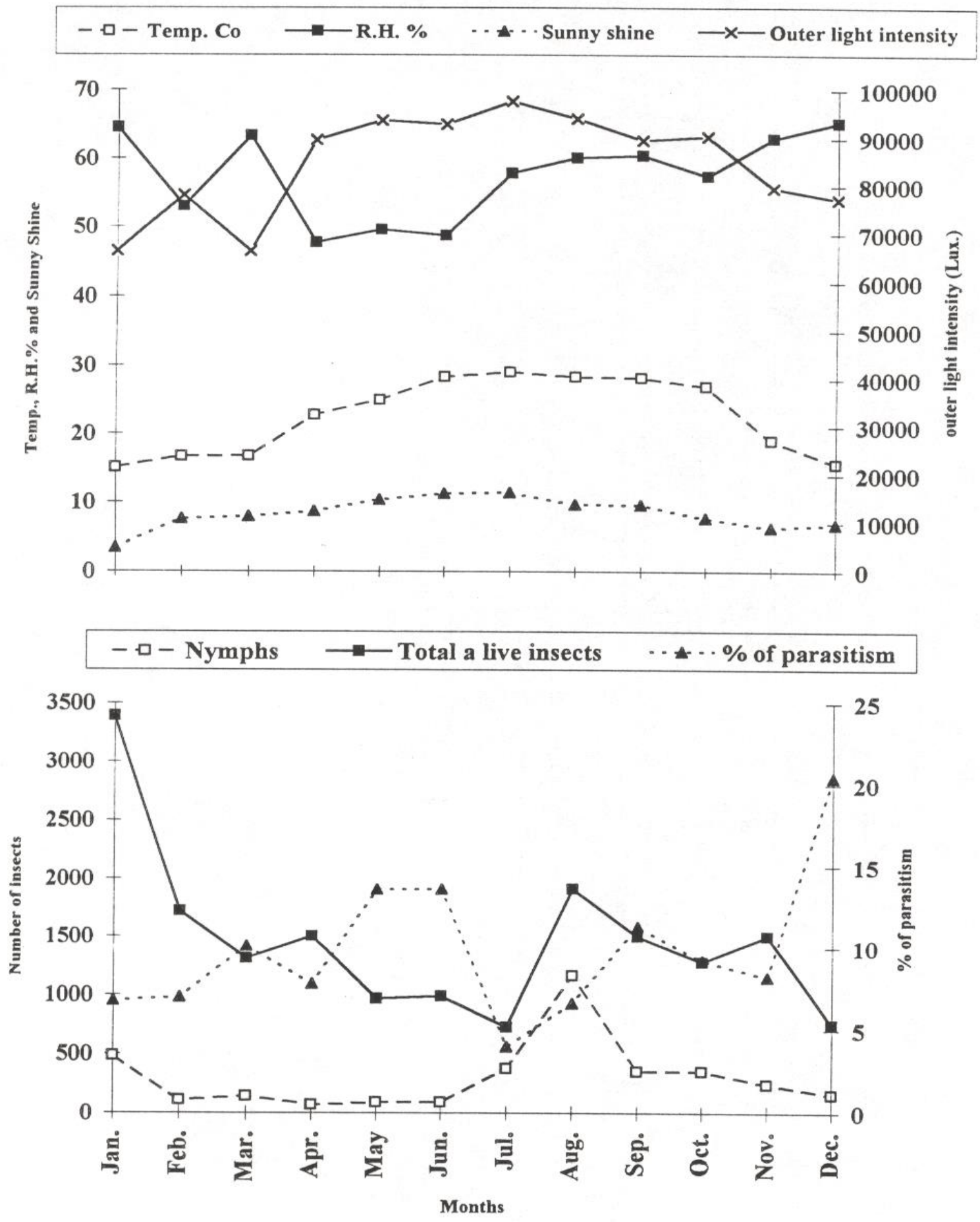

Fig. 1. Seasonal abundance of Parlatoria oleae and percentage of parasitism in outer zone of olive trees during the first season 1994. 

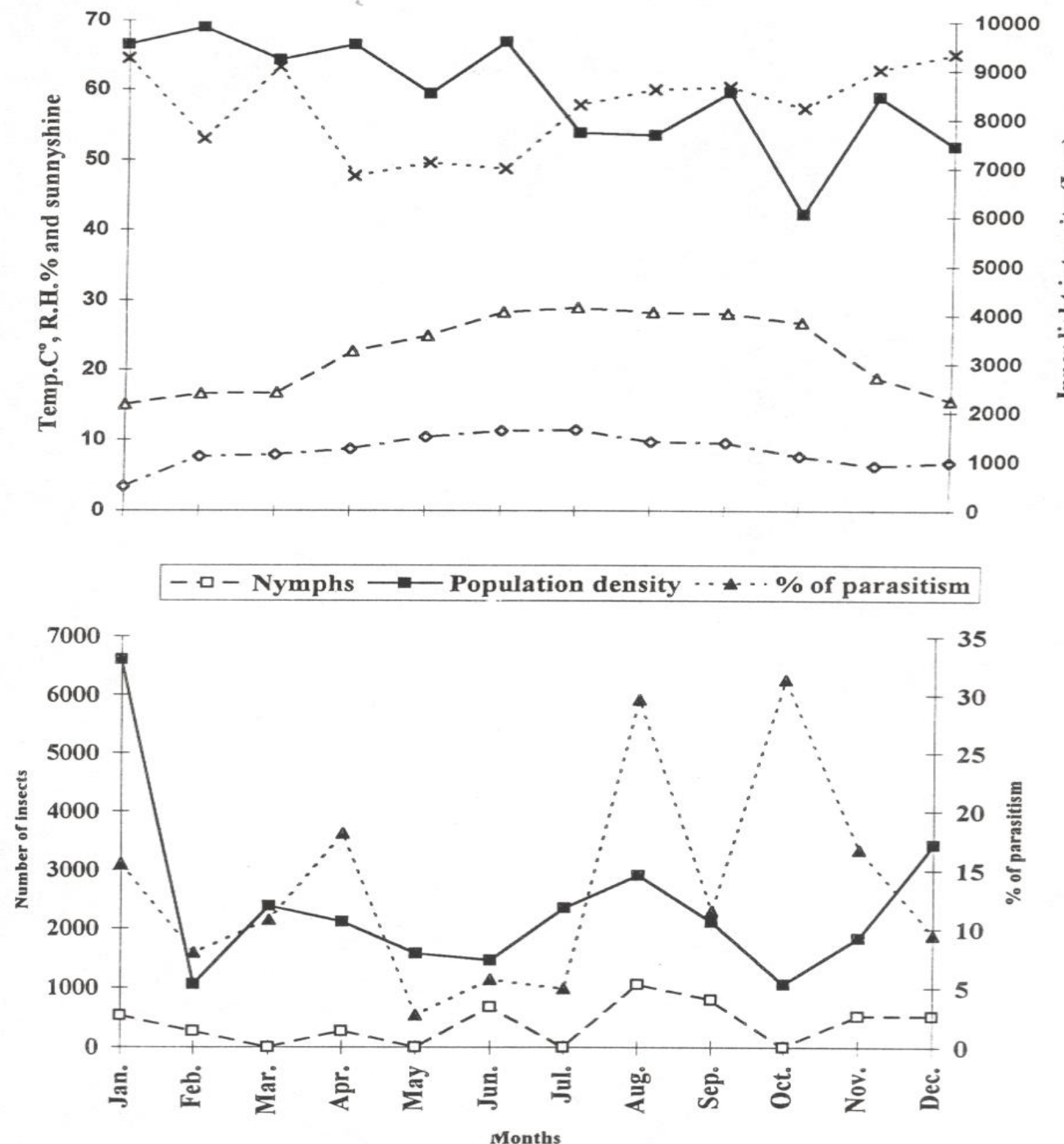

Fig. 2. Seasonal abundance of Parlatoria oleae and percentage of parasitism in inner zone of olive trees during the First season 1994. 
$-\Delta-$ Temp. Co $\cdots * \cdots$ R.H. $\%-\infty \cdot$ Sunny shine $\rightarrow-$ Outerlight intensity (Lux)
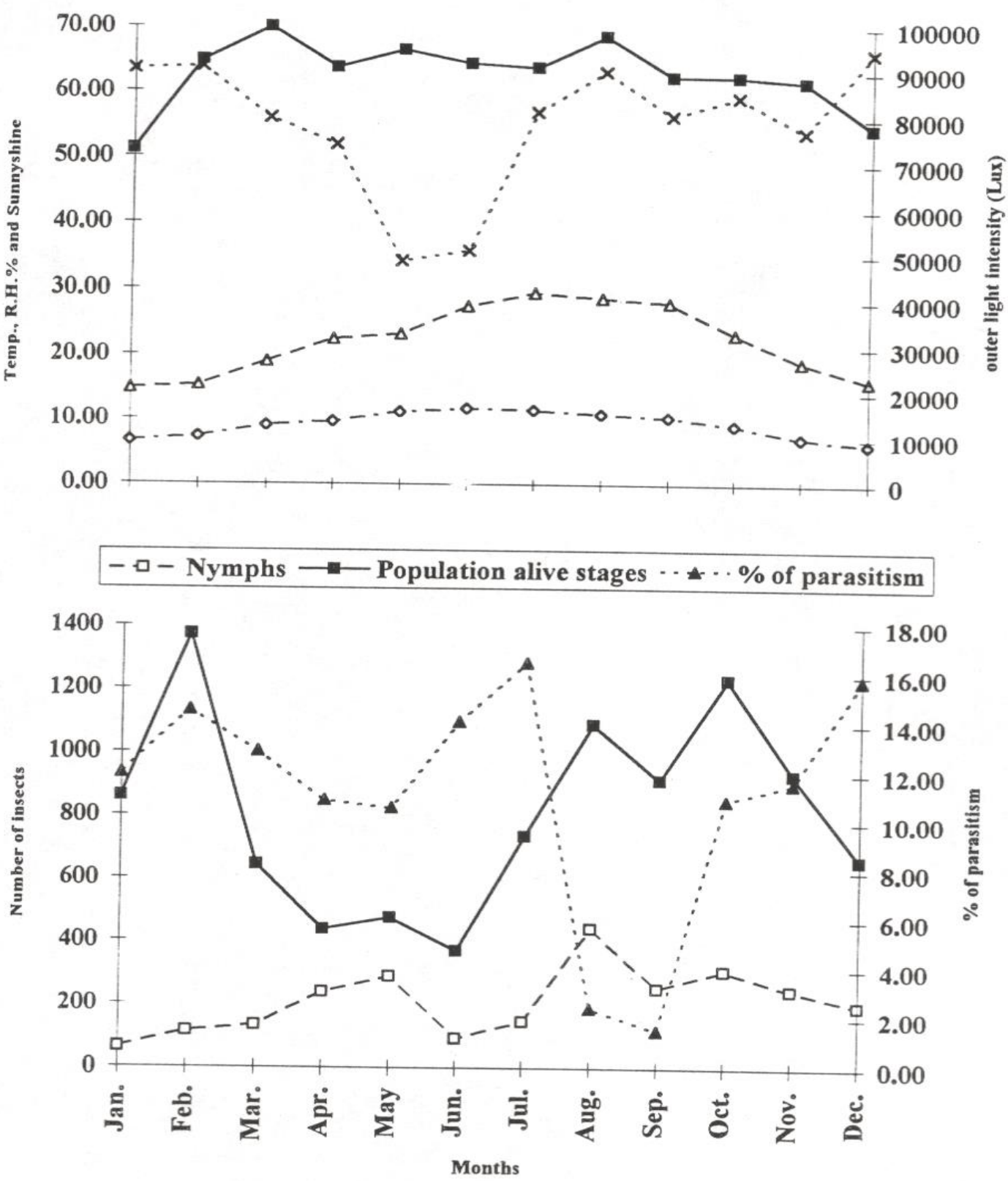

Fig. 3. Seasonal abundance of Parlatoria oleae and percentage of parasitism in outer zone of olive trees during the First season 1995. 


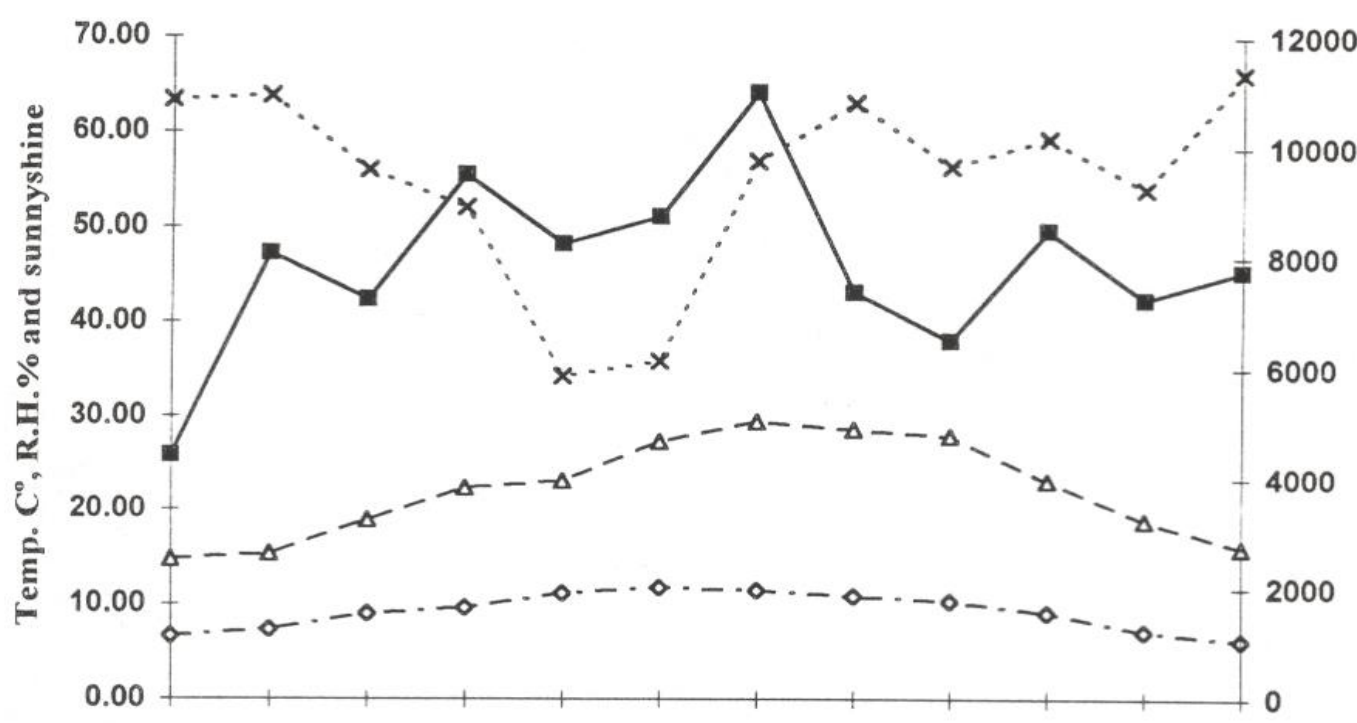

\section{$-\square-$ Nymphs $\longrightarrow-$ Total alive stages $\cdots \cdots \%$ of parasitism}

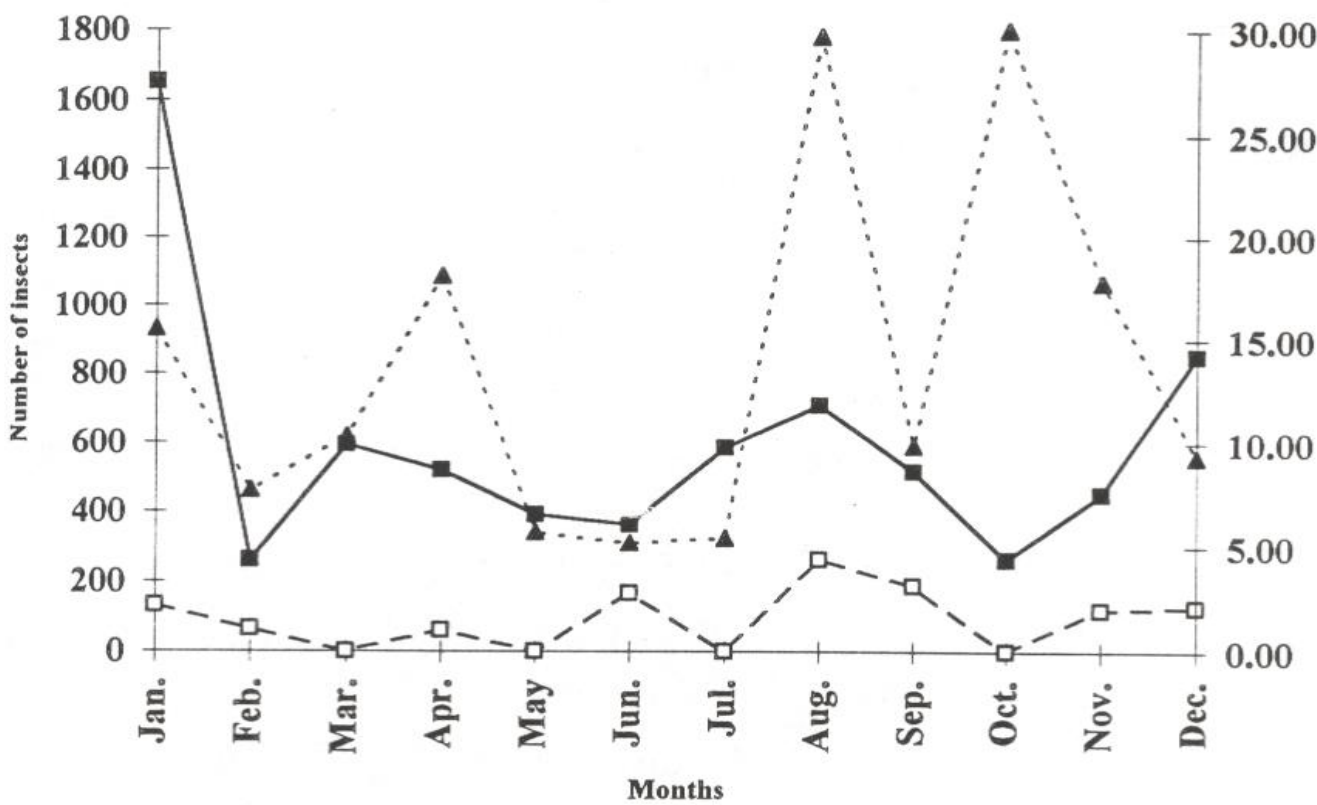

Fig. 4. Seasonal abundance of Parlatoria oleae and percentage of parasitism in inner zone of olive trees during the season 1995. 
1994

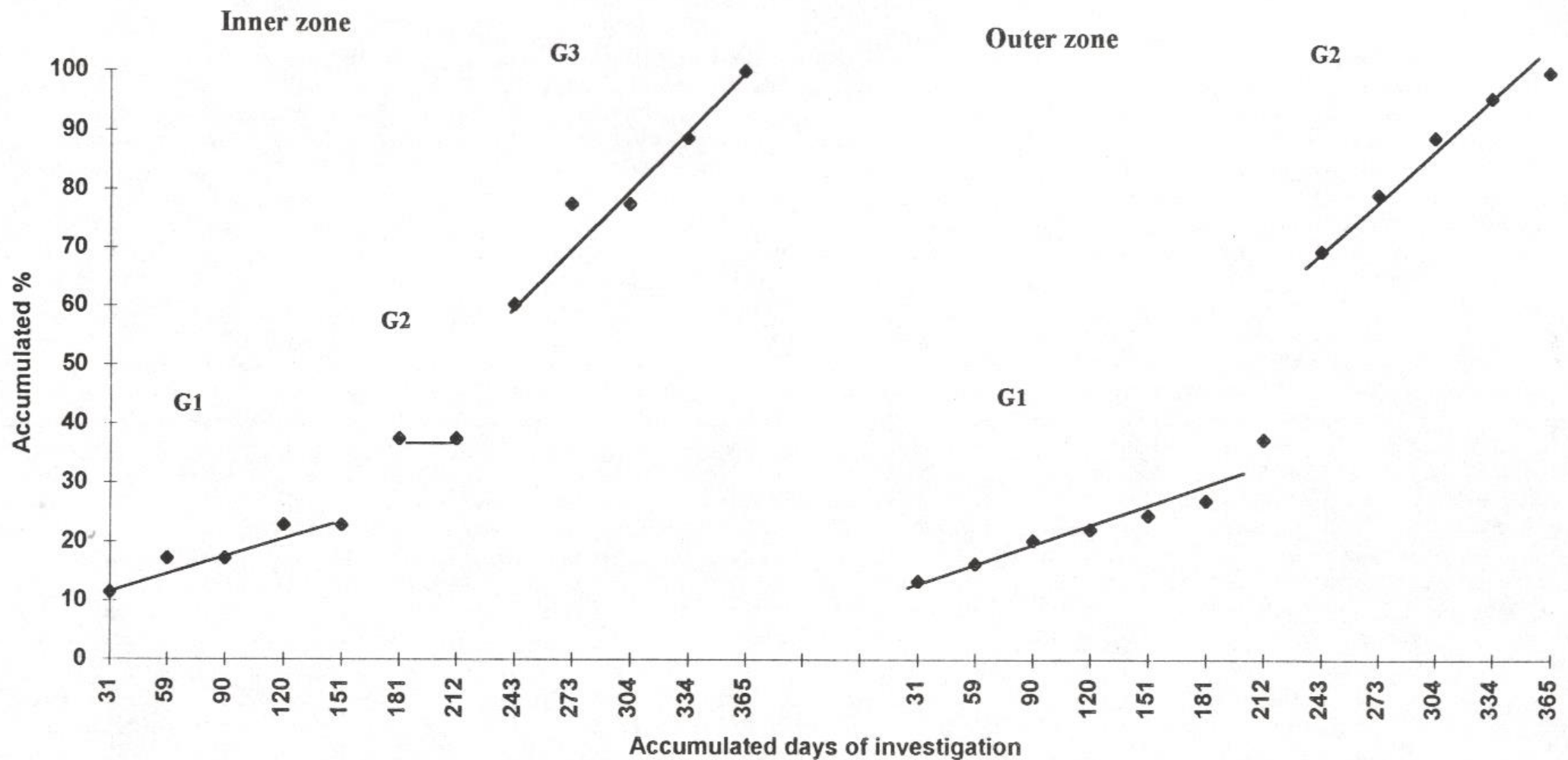

Fig. 5. Annual generations and duration of Parlatoria oleae on olive trees during the first season, 1994. 


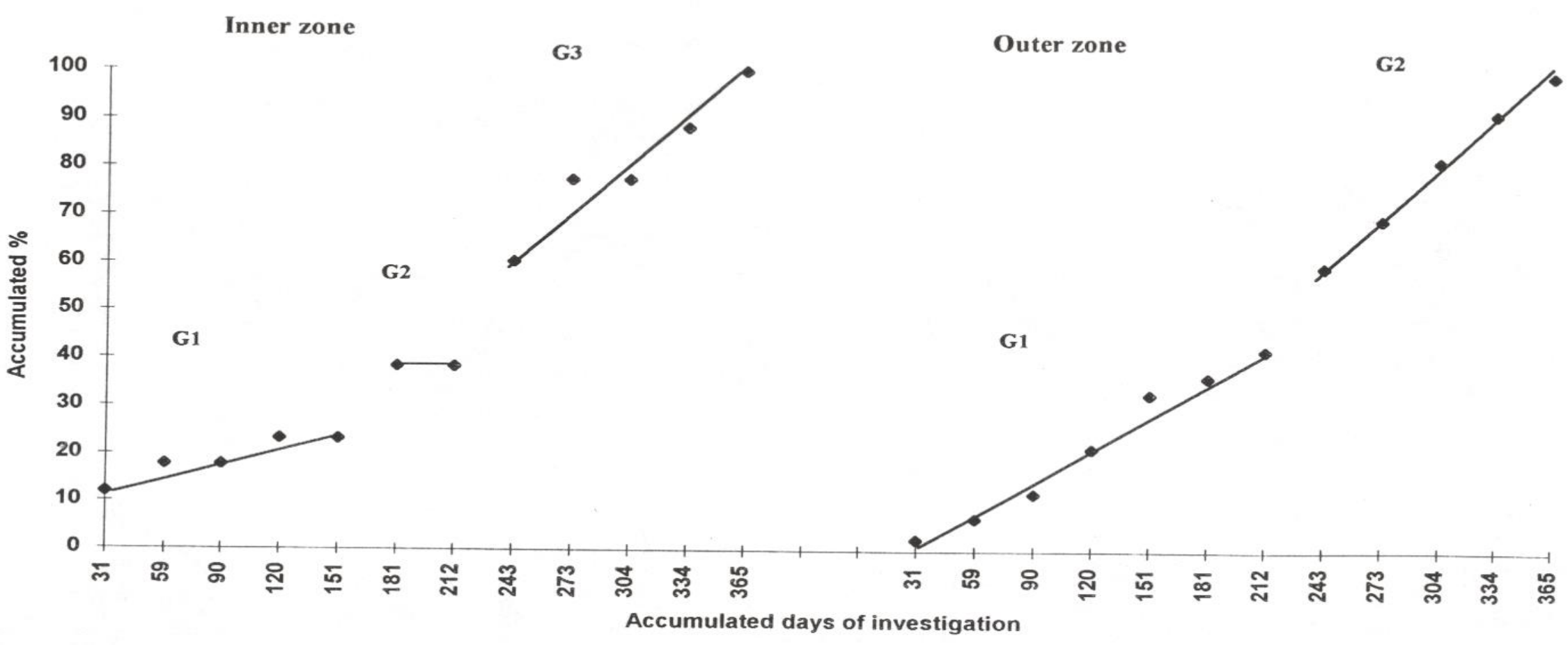

Fig. 6. Annual generations and duration of Parlatoria oleae on olive trees during the second season, 1995. 
Table 1. Seasonal abundance of Parlatoria oleae in outer zone on olive trees in El-Khattara region, Sharkia Governorate during season, 1994.

\begin{tabular}{|c|c|c|c|c|c|c|c|c|c|c|c|}
\hline \multirow{3}{*}{ Months } & \multicolumn{7}{|c|}{ Number of insects/960 twigs } & \multicolumn{4}{|c|}{ Monthly average of climatic factors } \\
\hline & \multicolumn{4}{|c|}{ Alive } & \multirow{2}{*}{$\begin{array}{l}\text { Total of non } \\
\text { alive insects }\end{array}$} & \multirow{2}{*}{ Mortality (\%) } & \multirow{2}{*}{ Parasitism (\%) } & \multirow{2}{*}{ Temp. $\left({ }^{\circ} \mathrm{C}\right)$} & \multirow{2}{*}{ R.H. (\%) } & \multirow{2}{*}{$\begin{array}{c}\text { Sunny } \\
\text { shine (hr.) }\end{array}$} & \multirow{2}{*}{$\begin{array}{l}\text { Light intensity } \\
\qquad \text { (Lux) }\end{array}$} \\
\hline & Females & Male & Nymphs & Total & & & & & & & \\
\hline Jan. & 770 & 2134 & 484 & 3388 & 4774 & 58.5 & 6.8 & 15.0 & 64.5 & 3.4 & 66400 \\
\hline Feb. & 838 & 770 & 110 & 1718 & 4070 & 70.3 & 7.0 & 16.6 & 53.0 & 7.6 & 78000 \\
\hline Mar. & 308 & 859 & 142 & 1309 & 3508 & 72.8 & 10.1 & 16.7 & 63.3 & 7.9 & 66400 \\
\hline Apr. & 245 & 1188 & 69 & 1502 & 3048 & 67.0 & 7.8 & 22.7 & 47.7 & 8.7 & 89600 \\
\hline May & 88 & 792 & 88 & 968 & 2432 & 71.5 & 13.6 & 24.9 & 49.6 & 10.4 & 93600 \\
\hline Jun. & 110 & 791 & 88 & 989 & 1760 & 64.0 & 13.6 & 28.3 & 48.8 & 11.3 & 92800 \\
\hline Jul. & 110 & 242 & 374 & 726 & 1495 & 67.3 & 4.0 & 29.0 & 57.9 & 11.4 & 97600 \\
\hline Aug. & 198 & 550 & 1161 & 1909 & 1396 & 42.2 & 6.6 & 28.3 & 60.1 & 9.7 & 94000 \\
\hline Sep. & 88 & 1056 & 352 & 1496 & 1210 & 44.7 & 11.3 & 28.2 & 60.5 & 9.6 & 89600 \\
\hline Oct. & 66 & 858 & 352 & 1276 & 1583 & 55.4 & 9.2 & 26.9 & 57.5 & 7.7 & 90400 \\
\hline Nov. & 113 & 1144 & 242 & 1499 & 1452 & 49.2 & 8.2 & 19.0 & 63.0 & 6.3 & 79600 \\
\hline Dec. & 88 & 506 & 154 & 748 & 1085 & 59.2 & 20.4 & 15.6 & 65.3 & 6.8 & 77200 \\
\hline Total & 3022 & 10890 & 3616 & 17528 & 27813 & 61.3 & 9.9 & & & & \\
\hline
\end{tabular}


Table 2. Seasonal abundance of Parlatoria oleae in inner zone on olive trees in El-Khattara region, Sharkia Governorate during season 1994.

\begin{tabular}{|c|c|c|c|c|c|c|c|c|c|c|c|}
\hline \multirow{3}{*}{ Months } & \multicolumn{7}{|c|}{ Number of insects/960 twigs } & \multicolumn{4}{|c|}{ Monthly average of climatic factors } \\
\hline & \multicolumn{4}{|c|}{ Alive } & \multirow{2}{*}{$\begin{array}{l}\text { Total of non } \\
\text { alive insects }\end{array}$} & \multirow{2}{*}{ Mortality (\%) } & \multirow{2}{*}{ Parasitism (\%) } & \multirow{2}{*}{ Temp. $\left({ }^{\circ} \mathrm{C}\right)$} & \multirow{2}{*}{ R.H. (\%) } & \multirow{2}{*}{$\begin{array}{c}\text { Sunny } \\
\text { shine (hr.) }\end{array}$} & \multirow{2}{*}{$\begin{array}{l}\text { Light intensity } \\
\qquad \text { (Lux) }\end{array}$} \\
\hline & Females & Male & Nymphs & Total & & & & & & & \\
\hline Jan. & 4488 & 1584 & 528 & 6600 & 24024 & 78.4 & 15.5 & 15.0 & 64.5 & 3.4 & 9500 \\
\hline Feb. & 792 & 000 & 264 & 1056 & 2288 & 68.4 & 7.9 & 16.6 & 53.0 & 7.6 & 9850 \\
\hline Mar. & 1320 & 1056 & 000 & 2376 & 12144 & 73.5 & 10.7 & 16.7 & 63.3 & 7.9 & 9181 \\
\hline Apr. & 528 & 1320 & 264 & 2112 & 3696 & 63.6 & 18.1 & 22.7 & 47.7 & 8.7 & 9500 \\
\hline May & 520 & 1056 & 000 & 1576 & 7656 & 82.9 & 5.7 & 24.9 & 49.6 & 10.4 & 8500 \\
\hline Jun. & 000 & 792 & 672 & 1464 & 3128 & 68.1 & 5.7 & 28.3 & 48.8 & 11.3 & 9050 \\
\hline Jul. & 516 & 1848 & 000 & 2364 & 1848 & 43.9 & 4.9 & 29.0 & 57.9 & 11.4 & 7700 \\
\hline Aug. & 264 & 1584 & 1056 & 2904 & 2376 & 45.0 & 29.6 & 28.3 & 60.1 & 9.7 & 7650 \\
\hline Sep. & 000 & 1320 & 792 & 2112 & 2368 & 52.9 & 11.5 & 28.2 & 60.5 & 9.6 & 8521 \\
\hline Oct. & 000 & 1056 & 000 & 1056 & 3168 & 75.0 & 31.3 & 26.9 & 57.5 & 7.7 & 6050 \\
\hline Nov. & 000 & 1320 & 516 & 1836 & 6072 & 76.8 & 16.7 & 19.0 & 63.0 & 6.3 & 8450 \\
\hline Dec. & 528 & 2376 & 520 & 3424 & 5016 & 59.4 & 9.4 & 15.6 & 65.3 & 6.8 & 7450 \\
\hline Total & 8956 & 15312 & 4612 & 28880 & 73784 & 71.9 & 13.9 & & & & \\
\hline
\end{tabular}


Table 3. Seasonal abundance of Parlatoria oleae in outer zone on olive trees in El-Khattara region, Sharkia Governorate during season, 1995.

\begin{tabular}{|c|c|c|c|c|c|c|c|c|c|c|c|}
\hline \multirow{3}{*}{ Months } & \multicolumn{7}{|c|}{ Number of insects/960 twigs } & \multicolumn{4}{|c|}{ Monthly average of climatic factors } \\
\hline & \multicolumn{4}{|c|}{ Alive } & \multirow{2}{*}{$\begin{array}{l}\text { Total of non } \\
\text { alive insects }\end{array}$} & \multirow{2}{*}{ Mortality (\%) } & \multirow{2}{*}{ Parasitism (\%) } & \multirow{2}{*}{ Temp. $\left({ }^{\circ} \mathrm{C}\right)$} & \multirow{2}{*}{ R.H. (\%) } & \multirow{2}{*}{$\begin{array}{c}\text { Sunny } \\
\text { shine (hr.) }\end{array}$} & \multirow{2}{*}{$\begin{array}{l}\text { Light intensity } \\
\text { (Lux) }\end{array}$} \\
\hline & Females & Male & Nymphs & Total & & & & & & & \\
\hline Jan. & 180 & 619 & 61 & 860 & 804 & 48.3 & 12.0 & 14.7 & 63.4 & 6.6 & 73000 \\
\hline Feb. & 216 & 1045 & 112 & 1373 & 1173 & 46.1 & 14.5 & 15.3 & 63.8 & 7.3 & 92667 \\
\hline Mar. & 127 & 384 & 131 & 642 & 762 & 54.3 & 12.9 & 18.9 & 56.0 & 9.0 & 100000 \\
\hline Apr. & 66 & 133 & 239 & 438 & 902 & 67.3 & 10.9 & 22.3 & 52.0 & 9.6 & 91000 \\
\hline May & 61 & 125 & 289 & 475 & 982 & 67.4 & 10.6 & 23.1 & 34.2 & 11.1 & 95000 \\
\hline Jun. & 95 & 184 & 91 & 370 & 918 & 71.3 & 14.1 & 27.3 & 35.8 & 11.7 & 92000 \\
\hline Jul. & 335 & 254 & 145 & 734 & 1126 & 60.5 & 16.5 & 29.4 & 56.9 & 11.4 & 90000 \\
\hline Aug. & 96 & 550 & 442 & 1088 & 513 & 32.0 & 2.4 & 28.6 & 63.1 & 10.8 & 98000 \\
\hline Sep. & 66 & 595 & 252 & 913 & 601 & 39.7 & 1.5 & 27.9 & 56.4 & 10.3 & 89000 \\
\hline Oct. & 66 & 858 & 308 & 1232 & 581 & 32.0 & 10.9 & 23.1 & 59.3 & 9.1 & 89000 \\
\hline Nov. & 44 & 640 & 247 & 931 & 570 & 38.0 & 11.6 & 18.8 & 54.0 & 7.1 & 88000 \\
\hline Dec. & 110 & 350 & 196 & 659 & 489 & 42.6 & 15.8 & 15.9 & 66.2 & 6.2 & 78000 \\
\hline Total & 1462 & 5737 & 2514 & 9715 & 9422 & 49.2 & 11.1 & & & & \\
\hline
\end{tabular}


Table 4. Seasonal abundance of Parlatoria oleae in inner zone on olive trees in El-Khattara region, Sharkia Governorate during season, 1995.

\begin{tabular}{|c|c|c|c|c|c|c|c|c|c|c|c|}
\hline \multirow{3}{*}{ Months } & \multicolumn{7}{|c|}{ Number of insects/960 twigs } & \multicolumn{4}{|c|}{ Monthly average of climatic factors } \\
\hline & \multicolumn{4}{|c|}{ Alive } & \multirow{2}{*}{$\begin{array}{l}\text { Total of non } \\
\text { alive insects }\end{array}$} & \multirow{2}{*}{ Mortality (\%) } & \multirow{2}{*}{ Parasitism (\%) } & \multirow{2}{*}{ Temp. $\left({ }^{\circ} \mathrm{C}\right)$} & \multirow{2}{*}{ R.H. (\%) } & \multirow{2}{*}{$\begin{array}{c}\text { Sunny } \\
\text { shine (hr.) }\end{array}$} & \multirow{2}{*}{$\begin{array}{l}\text { Light intensity } \\
\qquad \text { (Lux) }\end{array}$} \\
\hline & Females & Male & Nymphs & Total & & & & & & & \\
\hline Jan. & 1124 & 396 & 132 & 1652 & 6004 & 78.4 & 15.5 & 14.7 & 63.4 & 6.6 & 4430 \\
\hline Feb. & 196 & 000 & 64 & 260 & 572 & 68.8 & 7.7 & 15.3 & 63.8 & 7.3 & 8083 \\
\hline Mar. & 332 & 260 & 00 & 592 & 3032 & 83.7 & 10.3 & 18.9 & 56.0 & 9.0 & 7250 \\
\hline Apr. & 132 & 328 & 60 & 520 & 916 & 63.8 & 18.1 & 22.3 & 52.0 & 9.6 & 9500 \\
\hline May & 128 & 264 & 00 & 392 & 1912 & 83.0 & 5.7 & 23.1 & 34.2 & 11.1 & 8250 \\
\hline Jun. & 000 & 196 & 168 & 364 & 780 & 68.2 & 5.2 & 27.3 & 35.8 & 11.7 & 8750 \\
\hline Jul. & 124 & 460 & 00 & 584 & 448 & 43.4 & 5.4 & 29.4 & 56.9 & 11.4 & 11000 \\
\hline Aug. & 56 & 388 & 264 & 708 & 600 & 45.9 & 29.7 & 28.6 & 63.1 & 10.8 & 7375 \\
\hline Sep. & 000 & 328 & 188 & 516 & 588 & 53.3 & 9.8 & 27.9 & 56.4 & 10.3 & 6500 \\
\hline Oct. & 000 & 264 & 00 & 264 & 828 & 75.8 & 30.0 & 23.1 & 59.3 & 9.1 & 8500 \\
\hline Nov. & 000 & 332 & 120 & 452 & 1412 & 75.8 & 17.8 & 18.8 & 54.0 & 7.1 & 7250 \\
\hline Dec. & 132 & 592 & 128 & 852 & 1260 & 59.7 & 9.3 & 15.9 & 66.2 & 6.2 & 7750 \\
\hline Total & 2224 & 3808 & 1124 & 7156 & 18352 & 71.9 & 13.7 & & & & \\
\hline
\end{tabular}


Table 5. Statistical analysis based on correlation coefficient $(r)$ indicated the effect of climatic factors on different stages of Parlatoria oleae of outer zone on olive trees in El-Khattra region, Sharkia Governorate during the season 1994.

\begin{tabular}{|c|c|c|c|c|c|c|c|c|}
\hline & \multirow[b]{2}{*}{ Temp. $\left({ }^{\circ} \mathrm{C}\right)$} & \multirow[b]{2}{*}{ R.H. (\%) } & \multirow[b]{2}{*}{ Sunny shine (hr. } & \multirow{2}{*}{$\begin{array}{c}\text { Light } \\
\text { intensity (Lux) }\end{array}$} & \multicolumn{4}{|c|}{ Combined effect } \\
\hline & & & & & & $\begin{array}{l}\text { R.H. } \\
(\%)\end{array}$ & $\begin{array}{c}\text { Sunny } \\
\text { Shine (hr.) }\end{array}$ & $\begin{array}{c}\text { Light } \\
\text { intensity (Lux) }\end{array}$ \\
\hline Female & 0.0881 & 0.0629 & -0.0563 & $-0.6081^{*}$ & Temp. $\left({ }^{\circ} \mathrm{C}\right)$ & -0.4287 & $0.8123 * *$ & $0.9151^{* *}$ \\
\hline Male & -0.2985 & 0.1675 & $-0.7213 * *$ & -0.5534 & R.H. (\%) & & $-0.5866 *$ & $-0.5785^{*}$ \\
\hline Nymphs & 0.2319 & 0.3756 & -0.0096 & 0.1936 & Sunny shine & & & $0.8244 * *$ \\
\hline Total number of alive & -0.3847 & 0.2954 & $-0.6962 *$ & -0.2455 & & & & \\
\hline Total of non alive insects & -0.2735 & -0.0855 & -0.5149 & $-0.6364 *$ & & & & \\
\hline$\%$ of total mortality & -0.2936 & -0.4526 & -0.1754 & -0.2206 & & & & \\
\hline$\%$ of parasitism & -0.1833 & 0.0571 & 0.0196 & -0.0942 & & & & \\
\hline
\end{tabular}

Table 6. Statistical analysis based on correlation coefficient ( $r$ ) indicated the effect of climatic factors on different stages of Parlatoria oleae of inner zone on olive trees in El-Khattra region, Sharkia Governorate during the season 1994.

\begin{tabular}{|c|c|c|c|c|c|c|c|c|}
\hline & \multirow[b]{2}{*}{ Temp. $\left({ }^{\circ} \mathrm{C}\right)$} & \multirow[b]{2}{*}{ R.H. (\%) } & \multirow[b]{2}{*}{ Sunny shine (hr. } & \multirow{2}{*}{$\begin{array}{c}\text { Light } \\
\text { intensity (Lux) }\end{array}$} & \multicolumn{4}{|c|}{ Combined effect } \\
\hline & & & & & & $\begin{array}{l}\text { R.H. } \\
(\%)\end{array}$ & $\begin{array}{c}\text { Sunny } \\
\text { Shine (hr.) }\end{array}$ & $\begin{array}{c}\text { Light } \\
\text { intensity (Lux) }\end{array}$ \\
\hline Female & -0.5729 & 0.3493 & $-0.6846 *$ & 0.4192 & Temp. $\left({ }^{\circ} \mathrm{C}\right)$ & -0.4287 & $0.8123 * *$ & -0.4334 \\
\hline Male & 0.0058 & 0.5429 & -0.1201 & -0.4473 & R.H. (\%) & & $-0.5866^{*}$ & -0.2706 \\
\hline Nymphs & 0.1462 & 0.2277 & -0.0465 & 0.0692 & Sunny shine & & & -0.1639 \\
\hline Total number of alive & -0.4393 & 0.5559 & $-0.6268 *$ & -0.1905 & & & & \\
\hline Total of non alive insects & $-0.5988 *$ & 0.3446 & $-0.7100 * *$ & 0.3637 & & & & \\
\hline$\%$ of total mortality & -0.4841 & -0.1137 & -0.4767 & 0.3858 & & & & \\
\hline$\%$ of parasitism & 0.1672 & 0.2015 & -0.2717 & -0.5012 & & & & \\
\hline
\end{tabular}


Table 7. Statistical analysis based on correlation coefficient $(r)$ indicated the effect of climatic factors on different stages of Parlatoria oleae of outer zone on olive trees in El-Khattra region, Sharkia Governorate during the season 1995.

\begin{tabular}{|c|c|c|c|c|c|c|c|c|}
\hline & \multirow[b]{2}{*}{ Temp. $\left({ }^{\circ} \mathrm{C}\right)$} & \multirow[b]{2}{*}{ R.H. (\%) } & \multirow[b]{2}{*}{ Sunny shine (hr. } & \multirow{2}{*}{$\begin{array}{c}\text { Light } \\
\text { intensity (Lux) }\end{array}$} & \multicolumn{4}{|c|}{ Combined effect } \\
\hline & & & & & & $\begin{array}{l}\text { R.H. } \\
(\%)\end{array}$ & $\begin{array}{c}\text { Sunny } \\
\text { Shine (hr.) }\end{array}$ & $\begin{array}{c}\text { Light } \\
\text { intensity (Lux) }\end{array}$ \\
\hline Female & 0.0079 & 0.3223 & 0.0189 & -0.1277 & Temp. $\left({ }^{\circ} \mathrm{C}\right)$ & -0.3816 & $0.9115^{* *}$ & 0.4832 \\
\hline Male & -0.3711 & $0.6176^{*}$ & -0.5104 & -0.1347 & R.H. (\%) & & $-0.6299 *$ & -0.3789 \\
\hline Nymphs & 0.4378 & 0.0335 & 0.2889 & -0.3886 & Sunny shine & & & $0.6323 *$ \\
\hline Total number of alive & -0.1894 & $0.6669 *$ & -0.3662 & 0.0231 & & & & \\
\hline Total of non alive insects & -0.1009 & -0.3420 & 0.2812 & 0.2018 & & & & \\
\hline$\%$ of total mortality & 0.1500 & $-0.7260 * *$ & 0.4507 & 0.1752 & & & & \\
\hline$\%$ of parasitism & -0.4453 & -0.0554 & -0.2986 & -0.0650 & & & & \\
\hline
\end{tabular}

Table 8. Statistical analysis based on correlation coefficient ( $r$ ) indicated the effect of climatic factors on different stages of Parlatoria oleae of inner zone on olive trees in El-Khattra region, Sharkia Governorate during the season 1995.

\begin{tabular}{|c|c|c|c|c|c|c|c|c|}
\hline & \multirow[b]{2}{*}{ Temp. $\left({ }^{\circ} \mathrm{C}\right)$} & \multirow[b]{2}{*}{ R.H. (\%) } & \multirow[b]{2}{*}{ Sunny shine (hr. } & \multirow{2}{*}{$\begin{array}{c}\text { Light } \\
\text { intensity (Lux) }\end{array}$} & \multicolumn{4}{|c|}{ Combined effect } \\
\hline & & & & & & $\begin{array}{l}\text { R.H. } \\
(\%)\end{array}$ & $\begin{array}{c}\text { Sunny } \\
\text { Shine (hr.) }\end{array}$ & $\begin{array}{c}\text { Light } \\
\text { intensity (Lux) }\end{array}$ \\
\hline Female & -0.5483 & 0.2934 & -0.4543 & $-0.6259 *$ & Temp. $\left({ }^{\circ} \mathrm{C}\right)$ & 0.3816 & $0.9115^{* *}$ & 0.4860 \\
\hline Male & 0.0971 & 0.2973 & -0.1279 & -0.0353 & R.H. (\%) & & $-0.6299 *$ & -0.2992 \\
\hline Nymphs & 0.2090 & 0.1891 & -0.0046 & -0.4467 & Sunny shine & & & 0.0750 \\
\hline Total number of alive & 0.3699 & 0.4034 & -0.4287 & $-0.6386 *$ & & & & \\
\hline Total of non alive insects & -0.5640 & 0.1224 & -0.4450 & $-0.7106 * *$ & & & & \\
\hline$\%$ of total mortality & $-0.6050 *$ & -0.3234 & -0.3454 & -0.3732 & & & & \\
\hline$\%$ of parasitism & 0.0728 & 0.4009 & -0.1121 & -0.1864 & & & & \\
\hline
\end{tabular}


Table 9. Number of generations and duration of Parlatoria oleae on fig trees in El-Khattara region, Sharkia Governorate during the first season, 1994.

\begin{tabular}{|c|c|c|c|c|c|c|c|}
\hline \multirow[b]{2}{*}{ Months } & \multirow[b]{2}{*}{$\begin{array}{c}\text { Accumulated days of } \\
\text { investigation }\end{array}$} & \multicolumn{3}{|c|}{ Inner zone } & \multicolumn{3}{|c|}{ Outer zone } \\
\hline & & $\begin{array}{l}\text { Monthly } \\
\text { counts of } \\
\text { nymphs }\end{array}$ & $\begin{array}{l}\text { Accumulated monthly } \\
\text { counts }\end{array}$ & Accumulative (\%) & $\begin{array}{l}\text { Monthly } \\
\text { counts of } \\
\text { nymphs }\end{array}$ & $\begin{array}{l}\text { Accumulated monthly } \\
\text { counts }\end{array}$ & Accumulative (\%) \\
\hline Jan. & 31 & 528 & 528 & 11.45 & 484 & 484 & 13.38 \\
\hline Feb. & 59 & 264 & 792 & 17.17 & 110 & 594 & 16.43 \\
\hline Mar. & 90 & 00 & 792 & 17.17 & 142 & 736 & 20.35 \\
\hline Apr. & 120 & 264 & 1056 & 22.90 & 69 & 805 & 22.26 \\
\hline May & 151 & 00 & 1056 & 22.90 & 88 & 893 & 24.70 \\
\hline Jun. & 181 & 672 & 1728 & 37.47 & 88 & 981 & 27.13 \\
\hline Jul. & 212 & 00 & 1728 & 37.47 & 374 & 1355 & 37.47 \\
\hline Aug. & 243 & 1056 & 2784 & 60.36 & 1161 & 2516 & 69.58 \\
\hline Sep. & 273 & 792 & 3576 & 77.54 & 352 & 2868 & 79.31 \\
\hline Oct. & 304 & 00 & 3576 & 77.54 & 352 & 3220 & 89.05 \\
\hline Nov. & 334 & 516 & 4092 & 88.73 & 242 & 3462 & 95.74 \\
\hline Dec. & 365 & 520 & 4612 & 100 & 154 & 3616 & 100 \\
\hline
\end{tabular}


Table 10. Number of generations and duration of Parlatoria oleae on fig trees in El-Khattara region, Sharkia Governorate during the second season, 1995.

\begin{tabular}{|c|c|c|c|c|c|c|c|}
\hline \multirow[b]{2}{*}{ Months } & \multirow[b]{2}{*}{$\begin{array}{l}\text { Accumulated days of } \\
\text { investigation }\end{array}$} & \multicolumn{3}{|c|}{ Inner zone } & \multicolumn{3}{|c|}{ Outer zone } \\
\hline & & $\begin{array}{l}\text { Monthly } \\
\text { counts of } \\
\text { nymphs }\end{array}$ & $\begin{array}{l}\text { Accumulated monthly } \\
\text { counts }\end{array}$ & Accumulative (\%) & $\begin{array}{l}\text { Monthly } \\
\text { counts of } \\
\text { nymphs }\end{array}$ & $\begin{array}{l}\text { Accumulated monthly } \\
\text { counts }\end{array}$ & Accumulative (\%) \\
\hline Jan. & 31 & 132 & 132 & 11.96 & 61 & 61 & 2.43 \\
\hline Feb. & 59 & 64 & 196 & 17.75 & 112 & 173 & 6.88 \\
\hline Mar. & 90 & 0 & 196 & 17.75 & 131 & 304 & 12.09 \\
\hline Apr. & 120 & 60 & 256 & 23.19 & 239 & 543 & 21.60 \\
\hline May & 151 & 0 & 256 & 23.19 & 289 & 832 & 33.09 \\
\hline Jun. & 181 & 168 & 424 & 38.41 & 91 & 923 & 36.71 \\
\hline Jul. & 212 & 0 & 424 & 38.41 & 145 & 1068 & 42.48 \\
\hline Aug. & 243 & 264 & 668 & 60.51 & 442 & 1510 & 60.06 \\
\hline Sep. & 273 & 188 & 856 & 77.54 & 252 & 1762 & 70.09 \\
\hline Oct. & 304 & 0 & 856 & 77.54 & 308 & 2070 & 82.34 \\
\hline Nov. & 334 & 120 & 976 & 88.41 & 247 & 2317 & 92.16 \\
\hline Dec. & 365 & 128 & 1104 & 100 & 197 & 2514 & 100 \\
\hline
\end{tabular}




\section{REFERENCES}

1. Abou-Setta, M.M., 1981.The influence of certain spray parameters on the efficiency of insecticides for controlling scale insects on citrus trees. M.Sc. Thesis, Fac. of Agric., Ain shams Univ., Egypt.

2. Applebaum, S. W. and. D. Rosen. 1964. Ecological studies on the olive scale Parlatoria oleae. J. Econ. Entomol., 57: 847 - 850.

3. Audemard, H. and H. G. Milaire. 1975. Le pieeage carpocapse (Laspeyresia pomonella L.) avec une pheromone sexuelle de synthese: premiers resultats utilisables pour 1 estimation des populations et laconduite de la lutte. Ann. Zool. Ecol. Anim.,: 7-61.

4. Cermeli, M. 1966. The population dynamic of citrus scaleinsects and its application in chemical control. Memaria Sextas Jornadas agron. Soc Vemez. Ingen., 3: 7.

5. 1993. The population dynamics of plum scale Paraltoria oleae, on plum trees. Memaria sextas jornadas, Agron. Soc. Vemez. Ingen., 7 (3): $12-15$.

6. Cohen, H. 1993. Phenology of the plum scale insects, P. oieae, and the presence of parasitism upon the scale in apple orchards of Golden Heights. Hassadeh, June, 73 (9): 98 -100, Israel

7. EL-Bolok M. M., S.M Sweilem and R.Y. Abd -El- Aleem. 1985a. Effect of different levels of trees, different cardinal directions, tree core and leaf surface on the distribution of Parlatoria zizyiphus (Lucas) in correlation with the year seasons. Bull. Soc. Ent. Egypt. 65: 289 - 299.

8. $.1985 \mathrm{~b}$. Seasonal variation in the population of Parlatoria zizyphus (Lucas) at Giza region. Bull. Soc. Ent. Egypt., 65: 281- 288.

9. EL-Hakim, A.M. and E.I. Helmy. 1985. Survey and population studies on olive leaf pest in Egypt. Bull. Ent. Soc. Egypt., 64: 213 - 220.

10. Fawzia, A. Hassanien and A. R. Hamed. 1985. On the population dynamics of Hemiberlesia lataniae Signoret and its parasite Habrolepis aspidioti Compare \& Annecke in Egypt. Bull. Ent. Soc. Egypt. Econ., Ser., 14: 63 - 72.

11. Fisher, A.R. 1950. Statistical methods for research worker. (Text Book).

12. Gomaa, E.M. 1978. The violet oyster shell scale, P. oleae, Restitelnr Zashchita., 26 (11): 30 - 32, Bulgaria.

13. Hafez, M. 1967. Population dynamics of the Plum scale, Parlatoria oleae (Colvee), in Egypt. Bull. Soc. Ent. Egypt, LI: 347 - 357.

14. Hafez, M. and R.L. Doutt. 1954. Biological evidence of sibling species in Aphytis maculicornis (Masi) (Hymenoptera: Aphelinidae). Canad. Entomol., 86 (2): 90 - 96. 
15. Huffaher, C. B. 1980. New technology of pest control. John Wiley and Sons, New York, PP. 319-365.

16. 1986. Biological control of phytophaga by entomophagous insects. Comune di Cesena, 22: 131 -149.

17. C. E. Kennett and G. L. Finney. 1962. Biological control of Olive scale, Parlatoria oleae (Colvee), in California by imported Aphytis maculicornis (Mask.) (Hymenoptera: Aphelinidae). Hilgardia, 32: 541 - 636.

18. Jacob, N. 1977. Un model matematic pentru stabilirea limitelor economice de toloranta a atacului molilor fructelor in iupte integrata. Analele I. C. P. P., 15: 179.

19. Kamal EL-Din, Z. M. 1983. Studies on the scale insect, Leucaspis riccae (Targioni), Homoptera. M.Sc. These. Fac. of Agric., Zagazig Univ.

20. Kennett, C.E., C.B. Huffaker and G.L. Finney. 1966. The role of an ectoparasitic aphelinid. Coccophagoides Titilis Doutt in the control of Paralatoria oleae (Colvee). Hilgardia, 37 (9): 255 - 282.

21. Kuznetsov, N. 1966. Coccids as pests of conifers (in Russian). (Zashch. Rast, 1966, 7: 46 - 47), (C. F. R. A. E., 56, 1968).

22. Mahmoud, S. F. 1981. Ecological studies on the California red scale, and the purple scale insects on citrus trees and the effect of some recent insecticides on them and their parasites. M. Sc. Thesis. Fac. of Agric., Cairo Univ.

23. Mouris, K.S. and H. A. Mesbah. 1985. Olive pests of irrigated system in the Egyptian Western desert with special references to armored scale insect, Ann. Agric. Sc. Moshtohor, 23 (2): 901 - 911.

24. Moursi, K.S. and E.M. Hegazi. 1985. The olive trees scale Leucaspis riccae and Parlatoria eaef (Homoptera: Diaspididae) as a key pests of olive trees in dry farm system in the Egyptian Western desert. Bull. Lab. Entomol. Fillippo Silvetri., Portici, 40: 119 - 124.

25. Nahla Abd- El-Halleem A. 1997. Ecological studies on plum scale insect Parlatoria oleae and its parasitoid Aphytis sp on deciduous trees. Thesis M.Sc. Fac. of Agric. Cairo, Univ.

26. Shalom, W. and D. Rosen. 1964. Ecological studies on the Olive scale, Parlatoria oleae, in Israel. J. of. Econ. Ento. Vol. 57 No 6 PP. 847 - 850

27. Rizk, G.A. and O.S. Mohamed. 1985. Ecological studies on the plum scale insect, Parlatoria oleae (Colvee) (Homop'era: Diaspididae) in Iraq. Zanco 3 (1): 77 -84. 


\title{
الوفرة الموسمية لحشرة البرقوق القشرية Parlatoria oleae (Colvee على أثجار الزيتون في المناطق المستصلحة حديثا
}

\author{
عبد المنعم شوقي حسن' ، منصور محمد منصور ' ، محمد على الديب' \\ - 1 \\ r- قسم وقاية النبات - كلبة الزراعة - جامعة الزقازيق
}

يهدف البحث إلى دراسة الوفرة الموسمية لحشرة البرقوق القشرية والتى تصيب أثنجار الزيتون في الأراضى المستصلحة حديثا ومدى تأثثرها على المحصول كما ونوعا وقد اشتملت أماكن الدراسة

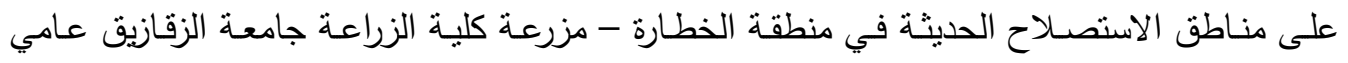
$.1990,199 \varepsilon$

وكانت النتائج المتحصل عليها كالتالي:

- سجل لهذه الحشرة ب ذروات على أنثجار الزيتون في منطقة الخطارة - محافظة الثرقية

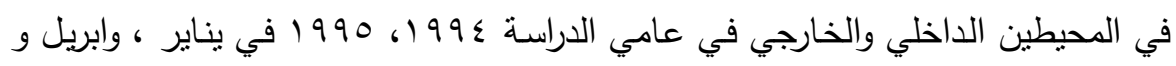

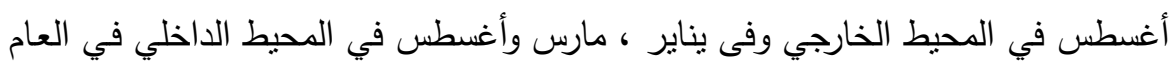

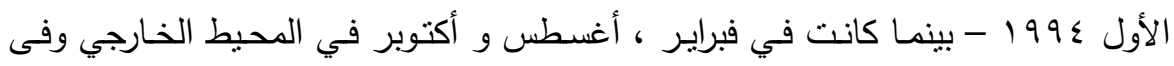

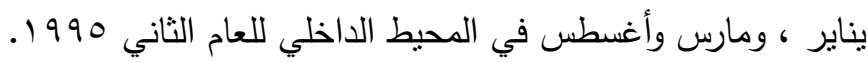
- أن أعلى ذروة سجلت في المحيط الداخلي والخارجي خلال عامي الدراسة كانت في يناير ماعدا في المحيط الخارجي عام 1990 سجلت في فبراير

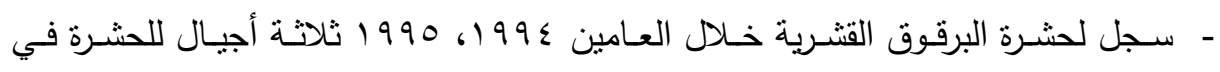
المحيط الداخلي بينما كانت جيلين في المحيط الخارجي وان اقوي هذه الأجيال كان الجيل الأخير في المحيط الداخلي والخارجي خلال عامي الدراسة.

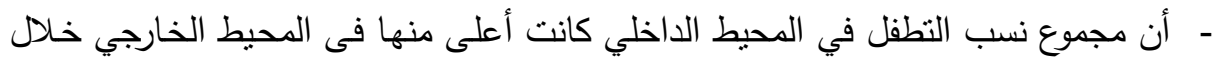

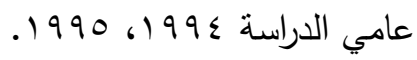
Marietta picta،Marietta connecte، Aphytis sp سـجلت الطفيليـات ل Hyperparasites, وجد ارتباط عالي المعنوية بين كل من درجات الحرارة وعدد ساعات النهار وكذلك وجد ارتباط معنوي سالب بين الرطوبة النسبية وعدد ساعات النهار وذلك على جميع أطوار الحشرة والطفيل. 